Housing Pathways of Skilled Migrants : Indian Professionals in Helsinki, Finland

\title{
Eskelä, Elina
}

2018

Eskelä , E 2018 , ' Housing Pathways of Skilled Migrants : Indian Professionals in Helsinki,

Finland ', Housing, Theory and Society , vol. 35 , no. 4 , pp. 474-494 . https://doi.org/10.1080/14036096.2017.13871

http://hdl.handle.net/10138/311207

https://doi.org/10.1080/14036096.2017.1387172

cc_by_nc_nd

acceptedVersion

Downloaded from Helda, University of Helsinki institutional repository.

This is an electronic reprint of the original article.

This reprint may differ from the original in pagination and typographic detail.

Please cite the original version. 


\title{
Housing Pathways of Skilled Migrants: Indian Professionals in Helsinki, Finland
}

\begin{abstract}
Although relatively understudied, the role of affordable and acceptable housing in the accelerating global competition for talent is of utmost importance, especially if highly skilled migrants are to be absorbed into the permanent labour force. This paper concerns the housing of skilled Indian migrants in the Helsinki metropolitan area in Finland, and contributes to the literature on international migration and the housing of ethnic minorities. It presents a case study on how to analyse migrants' housing pathways, examining the meaning of housing in the transnational lives of this relatively affluent migrant group. The results show that homeownership is a not a simple indicator of commitment to the host society, and that those responsible for national housing policy need to ensure the supply, quality and reasonable price of accommodation in order to fulfil the housing needs of skilled migrants.
\end{abstract}

Keywords: migration, home ownership, housing choice, housing pathways, Finland

\section{Introduction}

The housing of ethnic minorities is frequently discussed in the context of residential segregation and discriminatory practices, whereas housing as an amenity and the residential satisfaction of skilled migrants has received less attention. This is somewhat surprising given that increasing international migration among the skilled has generally provoked city regions into considering their attractiveness in the eyes of the "creative class' (Florida 2004). Indeed, soft factors such as urban amenities and local lifestyles have been acknowledged as important, especially in retaining skilled migrants in a city region (Khoo et al. 2008, 222; Pethe et al. 2010, 188). Moreover, research on the housing of skilled migrants is scant in comparison with the rich literature on the housing of low-skilled immigrant groups. However, the residential satisfaction of skilled migrants is very important from the perspective of the host cities aiming to retain them, 
and is assumed to play a key role in whether people move away from or stay in their current location (Rossi 1955/1980; Speare 1974).

There is a growing body of literature (Robinson \& Reeve 2006; Robinson 2010; Phillips et al. 2014) discussing the residential segregation, housing experiences and neighbourhood effects of new immigrants - mostly low-skilled - in the UK. To understand the complex nature of housing in the lives of new migrants, a housing pathways approach has been adopted to overcome the problems related to earlier research approaches, which have been criticised for portraying the agency of ethnic minority people as too limited and ethnic minority groups as too uniform (Robinson et al. 2007). A housing pathways approach (Clapham 2002, 2005) offers an interesting analytical framework for studying the meaning of housing in the lives of career-oriented skilled migrants, as "a housing pathway will run alongside and be closely associated with other types of pathways such as employment” (Clapham 2005,30).

Contemporary India is known for the emigration of skilled workers: Indians constitute a notable, educated pool of workers (Agrawal \& Lovell 2010) and entrepreneurs (Saxenian 2006, 49-50, 58) in their destination countries, and are generally a highly educated and potentially well integrated minority group with good English-language skills (Skop 2007). Indian professionals are a growing immigrant group also in Finland: in 2012, half of those who were granted residence permits on a specialist basis were of Indian origin (Yle News 2013). As a generally educated and professional migrant group, Indians are an excellent example for studying the housing of skilled migrants.

The present paper aims to widen existing knowledge about the housing of skilled migrants in two ways. First, it presents an exploratory study on how to analyse skilled migrants' housing pathways, taking structures, agency and (transnational) social 
interactions into account. Second, the study of Indian migrants in the Helsinki metropolitan area (HMA) gives a fresh perspective on this established migrant group outside of the normal World City context, widening the scope of empirical data on skilled migrants' perceptions of their host cities (Meier 2015; Walsh 2014; Yanasmayan 2015). The study, based on interview data concerning the housing pathways of skilled Indian migrants in the HMA, addresses two research questions. 1) What are the housing pathways of skilled Indian migrants in the HMA and what factors affect their residential satisfaction? 2) What is the role of housing and homeownership in the future plans of these migrants?

The paper is structured as follows. First, I discuss literature on skilled migrants and their housing. The next section reviews different research approaches on ethnicminority housing, presents a housing pathways approach and justifies its use in this particular study. A description of the study area follows, concentrating on housing and immigration in Finland, after which the data and the methods used are described. The results section focuses, first, on these Indians' housing pathways and their residential satisfaction, and second on the relationship between homeownership and their future plans. In conclusion, I discuss the findings of the study and make recommendations concerning housing policy on an international level.

\section{Skilled Migration and Housing}

Interest in skilled immigration has been fuelled by the growing importance of skills and knowledge in the new economic climate (Castells 2010; McCann\& Acs 2011). Skilled migrants could be described as educated professionals (Iredale 2001): most of them have a tertiary education and/or work in positions requiring such qualifications (Ryan \& Mulholland 2013). Cities that are able to attract and retain skilled migrants stand to gain competitive advantage (Douglass et al. 2001; Wadhwa et al. 2008), and skilled Indian 
and Chinese immigrants have played an important role in Silicon Valley's economic success, for instance (Saxenian 2006).

Academics have discussed the factors affecting the migration decisions of professionals intensively for over a decade. Some authors highlight the importance of urban amenities (Glaeser et al. 2001, Florida 2004), and extensive literature has provided many insights on which amenities are important for knowledge workers (for a summary, see e.g. Yigitcanlar et al. 2007): shopping and cultural amenities, quality childcare and healthcare services, "authentic" and "historical" places, as well as affordable housing. Others argue that hard factors such as job opportunities are dominant (Storper \& Manville 2006; Niedomysl \& Hansen 2010). In Europe, studies have shown that while hard factors are important for professionals, also social networks and "regional amenities" influence the attractiveness of areas in Europe (RodríguezPose \& Ketterer 2012; Musterd \& Kovács 2013).

Studies on the housing of the "creative class" (Florida 2004) have been similarly contradictory. A study in the Netherlands (Van Oort et al. 2003) found that for the employees in the Information, Communication and Technology sector (ICT) dwelling and the residential area were more important than the proximity of the workplace. In other words, they stressed the quality of housing over commuting time. Another study in Dublin (Lawton et al. 2013) on the housing of workers of the creative and knowledge industries stresses the importance of classic factors, such as housing cost and accessibility, as well as the relevance of the life-cycle, including having a family, in their residential choice.

Whereas the general qualities of city regions and the housing of skilled workers have been under scrutiny, the housing of skilled migrants has not gained much detailed attention. Studies analysing the settlement patterns of skilled migrants (Aalbers \& 
Deurloo 2003; Kauppinen 2002; White 1998) note their tendency to concentrate in certain parts of city regions, usually in more affluent neighbourhoods that differ from the areas in which other ethnic minorities tend to live. However, information on settlement patterns does not cover residential satisfaction or the reasons behind specific housing choices. A rare example giving more insight into the residential choices of skilled migrants (White \& Hurdley 2003) showed that major factors in the choice of housing of Japanese skilled workers in London included neighbourhood safety, location in relation to the workplace, the condition and size of the dwelling and the availability of facilities such as Japanese schools and specialist shops. The importance of relocation services, including help with housing search, in the smooth settlement of skilled migrants has also been acknowledged (Kim 2014; Meier 2015).

It appears that the image of the city affects the choice of residential area: London has been described as potentially threatening and chaotic, thereby highlighting the need for safe residential areas (White \& Hurdley 2003), whereas Singapore is described as a 'city of social harmony' (Meier 2015, 66) in which the need for social mapping does not arise. The migrants' background as well as the situational conditions affect housing decisions. Morris and Winter (1975) argue that families evaluate their housing in terms of situational cultural norms, which are dependent on the society in which they live, and on inner family norms. If these norms are not met, resulting "normative housing deficit" is adjusted through residential mobility, or residential or family adaptation. Residential satisfaction and normative housing deficits are good predictors of the propensity to move (Morris et al. 1976).

Homeownership has been taken as a sign of commitment to the new country and a symbol of residential assimilation (Alba \& Logan 1992; Clark 2003; Murdie \& Teixeira 2003). However, the rates of ownership appear to vary among different ethnic 
groups (Brown \& Webb 2012; Coulson et al. 2003), and homeownership rates tend not to be as high among immigrants as in the native population.

\section{Ethnic Minority Housing and a Housing Pathways Approach}

There is an abundance of research on the housing of various immigrant and ethnic groups, and studies on the housing of ethnic minorities go back to the beginning of the $20^{\text {th }}$ century and the Chicago School of urban sociologists (Burgess 1925; Park 1915). One of the most widely discussed issues in the housing of immigrants is the process that puts them in a particular situation.

According to the structural explanation, societal structures constrain the housing choices of ethnic minorities: research has shown that they face discriminatory practices in the housing market (Aalbers 2002; Andersson 1998; Massey \& Denton 1993). Moreover, immigrants tend to reside in less desirable neighbourhoods in many cities (Bolt \& van Kempen 2002; Magnusson \& Özüekren 2002). They also have less knowledge about the local housing market, which affects their housing outcomes (Özüekren \& van Kempen 2003).

Other researchers argue that, despite the existence of structural burdens, individual choices drive the formation of ethnic-minority housing. According to Dahya's pioneering study (1974), Pakistanis in Britain wanted to minimise their housing costs in order to send remittances back home and they settled for the cheapest accommodation available.. Dahya (1974) further argues that their intention to return to their home country, "the myth of return", affects the immigrants' commitment to the host country, and they do not regard their house in Britain as 'home'. Anwar (1979) refers to the 'incapsulation' of Pakistanis in Britain, which is manifested in their residential segregation, their work life and dependence on their ethnic community. Later studies have shown that the myth of return is present also in the housing decisions of 
other low-income groups such as Ghanaians in Toronto (Owusu 1998), Greek-Cypriot refugees in Cyprus (Zetter 1999) and Senegalese in Italy (Sinatti 2011).

A third approach seeks to overcome the dualism and the static nature of the “choice-constraints" debate. Drawing from Giddens' structuration theory, “constrained choices" approach (Sarre 1986; Sarre et al. 1989) acknowledges the limitations that ethnic minorities face in the housing market, but also their capabilities to make choices. Structures are not only limiting, but they are also enabling, and they involve both rules and resources. Choice and constraint are intertwined and their roles change over time, as in Sarre's (1986) description on ethnic housing in Bedford.

However, all these above mentioned perspectives have been criticised for simplifying the situations and diminishing ethnic minorities into tight categories (Ratcliffe 2002). Also the dynamics of migration and housing differ from the situation described by the older literature. In the context of the UK, new migration (Robinson et al. 2007; Robinson 2010, Phillips et al. 2014) refers to the larger flows of immigrants since the early 1990's who originate from various countries, and whose presence is manifested in the new geographies of settlement beyond traditional receiving metropolitan cities.

The concept of housing pathways (Clapham 2002, 2005) has been brought up in the context of new migration to help to grasp the complex reality and meanings of current ethnic housing. The concept of housing pathways is defined as "patterns of interaction (practices) concerning house and home, over time and space" (Clapham 2002, 63). A housing pathways approach, drawing from social constructionism and structuration, is to be used as a framework of analysis, and not as a theory. While a housing career usually describes the quantitative aspects of housing (eg. price, size and tenure), housing pathways adds to these the layer of social meanings and relationships, 
such as the dwelling as a part of the lifestyle choice or the sense of community in the neighbourhood.

A housing pathways approach has been utilised in recent literature as a tool for unfolding various housing phenomena, such as residential stability (Meeus \& De Decker 2015), homelessness (Fitzpatrick et al. 2013) and housing of low-income residents (Wiesel 2014). Robinson et al. (2007) have used a housing pathways approach in the research on new immigrants' housing in Sheffield: the housing careers of immigrants were described, along with examining the social relations, structures and meanings related to their housing. Robinson et al. see that a housing pathways approach helps to reveal immigrants'active housing choices that can also change in the course of time.

\section{Housing and Immigration in a Nordic Welfare State}

In Finland, urbanisation came late, and the welfare state developed later and more rapidly than in other Nordic countries. Finland's housing policy has traditionally been part of the welfare system, and the state strongly supports housing production and consumption (Vaattovaara et al. 2010: 257).Homeownership is the dominant type of tenure in Finland (Ruonavaara 2003, 53) and 'acquires an aura of successful normality' (Andersson et al. 2007, 169). Finnish housing policy supports homeownership via tax benefits and help for first-time buyers. In 2012, 65 per cent of Finnish households lived in owner-occupied dwellings (OSF 2013a). However, the homeownership rate is lower in the capital city of Helsinki: in 2013 it was 44 per cent (HRS 2015b).

Most of the Finnish housing stock was built after the Second World War, and blocks of flats are the dominant form, especially in the Helsinki metropolitan area (Vaattovaara et al. 2010: 209). Among the Nordic countries, Finland also has the largest proportion of small housing units and the smallest number of rooms per person 
(Lujanen \& Palmgren, 2004: 27-29).

The majority of immigrant households in Helsinki live in rental accommodation: in 2012, 42 per cent lived in social and 32 per cent in private rental housing (the corresponding figures for Finnish nationals were 20 and 25 per cent) (Foreigners in Helsinki 2014, 25). Fewer immigrants are homeowners in Finland than in Sweden and Denmark, which is believed to be attributable to their later arrival in the country (Skifter Andersen et al. 2013). Homeownership rates vary among immigrant groups: they are on similar levels among those from Nordic and West European countries and the native population, whereas the majority of immigrants from Sub-Saharan Africa live in social rental housing (Vaattovaara et al. 2010: 217-218). Asians (other than West Asians) are located somewhere in between these two groups. Access to social housing is meanstested. It is therefore not usually an option for skilled migrants, who have to rely on the private rental sector or become homeowners. In practice, skilled migrants start their housing pathway in Finland in the private rental sector, which accounted for 24 per cent of dwellings in Helsinki in 2013 (HRS 2015a). Private rental accommodation largely comprises flats, as most detached houses are owner-occupied. Private renting is not regulated: the market determines the rates.

The HMA still has a lower number of immigrants than other European cities. Among the total population of around 5.5 million in 2013 there were 289068 foreignlanguage speakers (5.3 per cent) and 207511 foreign nationals (3.8. per cent) in Finland (Table 1). The proportion of foreign-born people is still considerably lower than the OECD average, which was 12.6 per cent (OECD 2014). However, the proportion of residents speaking languages other than Finland's official languages (i.e. Finnish, Swedish or Sami) as their mother tongue is expected to rise notably to constitute over 20 per cent of Helsinki's population in 2030 (Foreigners... 2014). Almost half of the 
foreign nationals in Finland live in the HMA, which comprises the municipalities of Helsinki, Espoo, Vantaa and Kauniainen. Indians in Finland are also concentrated in the area: of the 4,372 Indian nationals in the country, 3,107 live in the HMA. Indians are the ninth largest group of foreign nationals in Finland, and in the HMA they are the fifth largest group of foreign nationals after Estonians, Russians, Somalis and Chinese.

Table 1. The immigrant population in Finland and in the HMA. Sources: HRS, 2015b; Population with foreign background, 2013

\begin{tabular}{|c|c|c|}
\hline December 31, 2013 & & Per cent of total population in Finland \\
\hline Total population in Finland & 5451270 & 100.0 \\
\hline Foreign language as mother tongue* & 289068 & 5.3 \\
\hline Foreign nationals & 207511 & 3.8 \\
\hline Estonian nationals & 44774 & 0.8 \\
\hline Russian nationals & 30757 & 0.6 \\
\hline Swedish nationals & 8382 & 0.2 \\
\hline Indian nationals & 4372 & 0.1 \\
\hline January 1, 2014 & & Per cent of total population in the HMA \\
\hline Total population in the HMA & 1090616 & $\begin{aligned} & 100.0\end{aligned}$ \\
\hline Foreign language as mother tongue* & 138389 & 12.7 \\
\hline Foreign nationals & 93685 & 8.6 \\
\hline Estonian nationals & 23634 & 2.2 \\
\hline Russian nationals & 10637 & 1.0 \\
\hline Somalian nationals & 4323 & 0.4 \\
\hline Indian nationals & 3107 & 0.3 \\
\hline
\end{tabular}

*Mother tongue other than Finnish, Swedish or Sami

Previous studies on skilled migrants in Finland (e.g. Raunio 2002; Kepsu et al. 2009; Merimaa \& Oilinki 2010) discuss their lives and experiences in the country, including migration process, working life and urban environments. Kepsu et al. 2009 noticed that when assessing their lives in the HMA, skilled migrants saw housing as the most problematic feature. Building on this notion, this study focuses more deeply on the housing of these migrants, utilising a housing pathways approach. 


\section{Data and Methods}

The research data consists of 15 semi-structured interviews with skilled Indian migrants, conducted in 2012. Given that the interest of the study was in the housing of skilled migrants, who are by definition educated and/or working in professional positions, only individuals with higher university degree and/or professional work position were interviewed. I recruited participants who had obtained a university degree before migrating to Finland, had moved to Finland for work purposes and were employed at the time. The interviewees' professional profile corresponds well with the highly skilled Indians observed in earlier studies (Saxenian 2006; Agrawal \& Lovell 2010; Burgers \& Touburg 2013).

I recruited the interviewees using selective snowballing, where interviewees gave the contact information of their Indian acquaintances, but I chose only individuals who matched the above mentioned criteria. Having four initial contact points helped to enhance versatility among the informants (Valentine 2005), and to ensure that not all of them belonged to the same social network. I found the first interviewees through the assistance of five Finnish persons who had contacts with Indian migrants working in two universities and two knowledge-intensive companies (Figure 1). Some of the interviewees gave me the contact details of acquaintances or friends: the interviewees reached via this snowballing method (F, G, I, N and O in Figure 1) were working in different organisations than those who recommended them for the research, however. Among the interviewees was one couple $(B+C$ in Figure 1), both of which met the criteria. The interviewees' workplaces included two universities, one research centre and four private companies. 


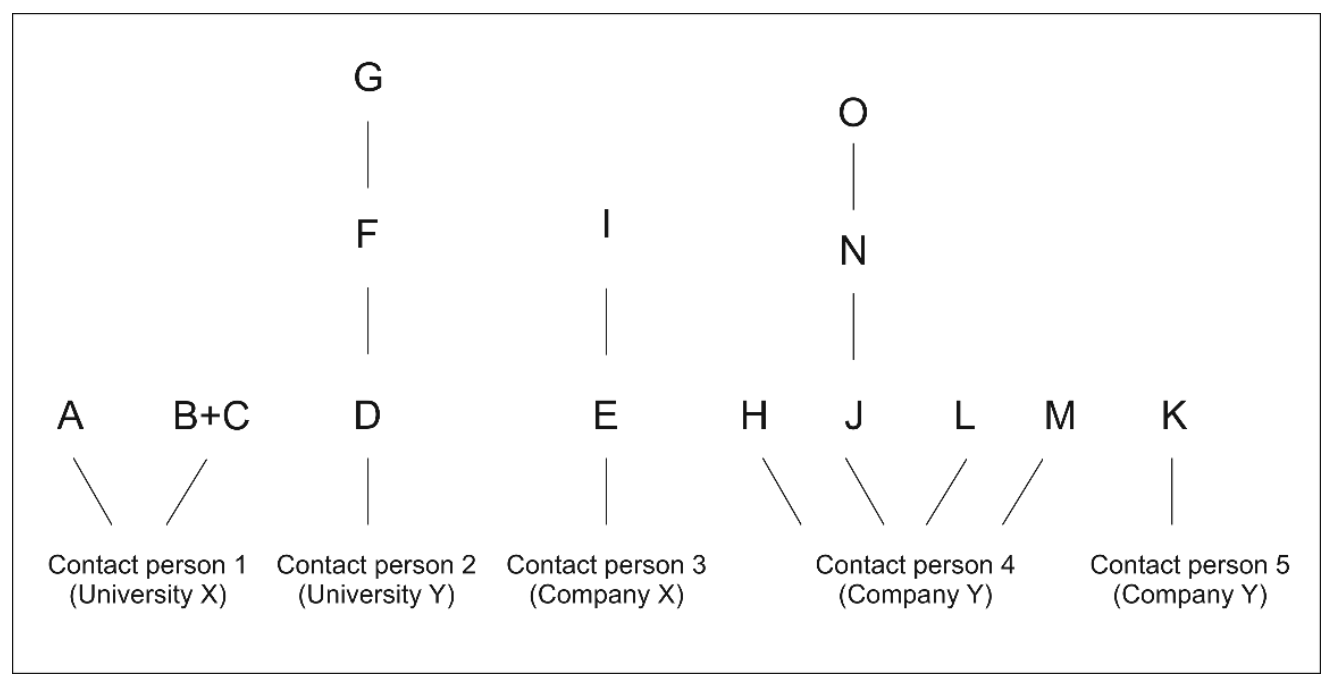

Figure 1. The selection of the interviewees $(\mathrm{A}-\mathrm{O})$ : five initial contact points and snowballing.

All the interviews were conducted in English, and were recorded and transcribed. The purpose of the interviews was to understand the choices and experiences of the individuals and households, as well as to identify structural aspects of national housing policy and housing practices. The themes included the interviewees' background and their move to Finland, their current accommodation and neighbourhood, their housing pathway in Finland and in their home country, lifestyle and social life, and future plans. The interviewees also filled in a form requesting background information such as education, countries of residence and monthly household net income.

I used the ATLAS.ti program for qualitative data in coding the material. The coding was based on the interview themes and interesting details that emerged from the data (Cope 2003, 449-450; Sánchez-Ayala 2012, 132-133). I used the concept of housing pathways (Clapham 2002, 2005) as an analytical framework and explored the meanings, social interactions, structures and agency in the immigrants' housing, building on previous applications of a housing pathways approach (Meeus \& De Decker 
2015; Fitzpatrick et al. 2013; Wiesel 2014), and especially on the study on new immigrants' housing pathways (Robinson et al. 2007).

Table 2 describes the interviewees' characteristics. These migrants were from various parts of India, and most of them had also obtained their university degrees in India. They all complied with the definition of 'migrant professionals' (Meier 2015a): they were employed as professionals in the fields of business and administration, science and IT. Most of them were in their 30s, which corresponds well with the overall demographic structure of Indians in Finland: almost two thirds of them are between 25 and 39 years old (OSF 2013b). All except three of the interviewees were men, most of them were married, and eight had children. All the spouses were Indian. Two men who were living alone in Finland had fiancées in India. The wives were working or studying (5), or stayed at home (5); the female interviewees' husbands were all working. The length of residence in Finland varied between seven months and eight years, about half of the interviewees having lived in the country for more than five years. One of them had been granted Finnish citizenship. Household income varied widely: one solebreadwinner family with children reported a monthly net income of between 2,000 and 3,000 euros, whereas another received more than 11000 euros per month. However, reported income may be error-prone in that combining all income in one question may result in underreporting or misreporting (Goldman \& Smith 2001: 1359), and there is a lot of potential for error in how income questions are understood and answered (Moore at al. 2000). 
Table 2. Background information on the Indian migrants

\begin{tabular}{|c|c|}
\hline \hline & Numbers of interviewees \\
\hline Age & $28-30$ years (5), 31-36 years (7), 37-41 years (3) \\
\hline Sex & male (12), female (3) \\
\hline Education & Bachelor's degree (1), Master's degree (8), PhD (6) \\
\hline Field of work & science (6), IT (2), marketing (2), management (3), HR (2) \\
\hline Has lived in Finland & less than two years (4), 2-4 years (4), 5-8 years (7) \\
\hline Employer & university/research institute (6), private company (9) \\
\hline Household & single (2), couple (5), couple with children (8) \\
\hline Household net income & euro (2), 9001-10 000 (1), more than 11 000 euro (1) \\
\hline \hline
\end{tabular}

At the time of the interviews all except one of the informants were living in the HMA: three in the municipality of Helsinki and 11 in the municipality of Espoo, and all except two of them worked in Espoo. One had moved to Tampere, a city $170 \mathrm{~km}$ from Helsinki, in connection with a project, but still kept a flat in Helsinki. Six of them were homeowners, and nine were renting.

Using the interview as a research method in examining the housing pathways of migrants made it possible to specify details and to ask follow-up questions, which in turn helped the researcher to react to unexpected or unclear issues (Dunn 2010, 103). 
Previous studies on immigrant housing (Tomlins et al. 2002; Dhalmann 2013) and skilled migrants (Meier 2015b; Mulholland \& Ryan 2015) support the use of semistructured interviews, and quotations from the interviews are used in this paper to enhance the transparency and reliability of the research (Silverman 2006, 282-283). However, as the data consists of 15 interviews collected through snowball sampling and the interviewees' time of residence in Finland varies greatly, this study is exploratory in nature and the results cannot be generalized. The data is further limited in that it predominantly describes the male perspective.

\section{Results}

\section{Housing Pathways of Skilled Indian Migrants in Helsinki}

The interviewees were very career-oriented and had come to Finland to acquire international experience, to establish contacts and to develop their professional skills. Many had applied for jobs internationally and eventually chose Finland for various reasons: Finland was renowned in fields such as IT and chemistry, for example, and for some it was important to be able to work in an English-speaking environment. A few also came to Finland on assignments through their positions in India. Finland as a country was not especially attractive to them: in fact, most of them said they knew nothing about the country beforehand.

Around half of the interviewees had never travelled outside India before moving to Finland. However, many had established transnational social ties before moving: only four of them did not know anyone in Finland beforehand, whereas others had contacts with colleagues or other Indian residents. All of these skilled Indian migrants received help from their employer in arranging housing before they moved to Finland, which echoes Kim's (2014) findings on corporate-driven skilled migrants in the USA. The 
help was in three different forms, and some interviewees were recipients of more than one kind of help: the employer paid a relocation agency to find suitable housing (7 interviewees) (however, one of the interviewees found a better place independently), arranged temporary housing for a fixed period (5 interviewees) or arranged rental housing either directly or by allocating the migrant to a housing system such as in university-owned dwellings ( 7 interviewees). Five interviewees also mentioned that the employer paid for a hotel accommodation before the first dwelling was secured. This initial help was considered valuable.

Table 3 provides a simplified presentation on the interviewees' housing careers, i.e. series of dwellings (Robinson et al. 2007, 4) in Finland. The interviewees have been arranged in the table in the order of their arrival in Finland. At the time of the interview in 2012, four migrants had lived in altogether five dwellings. They had lived in Finland between six and nine years. The newcomers, who had been in Finland around one year, still lived in their first flats. The duration of temporary accommodation in the beginning of the housing careers varied between one and four months. The difference in the socioeconomic situation shows markedly compared to the new immigrants in the UK, who received secure accommodation being in the country for over a year (Robinson et al. 2007). Those who had a rental flat with a continuing contract as their first dwelling lived there usually between one to two years. Generally, the more dwellings the migrants had lived in, the more likely it was that they had searched them by themselves. This is natural, since longer experience in residing in a country increases their information on the local housing market and enables them to act more independently. This finding echoes the discussion on the effect of individual choice on ethnic minority housing (e.g. Dahya 1974, Owusu 1998). 


\begin{tabular}{|c|c|c|c|c|c|c|c|c|c|c|c|}
\hline $\begin{array}{l}\text { Inter- } \\
\text { viewee }\end{array}$ & $\begin{array}{c}\text { Moved } \\
\text { to } \\
\text { Finland }\end{array}$ & $\begin{array}{c}\text { Total years in } \\
\text { Finland }\end{array}$ & 1. dwelling & reason to move & 2. dwelling & reason to move & 3. dwelling & reason to move & 4. dwelling & $\begin{array}{c}\text { reason } \\
\text { to } \\
\text { move }\end{array}$ & 5. dwelling \\
\hline $\mathrm{F}$ & 2003 & 9 & rental flat (1 y) & $\begin{array}{c}\text { moved } \\
\text { closer to } \\
\text { workplace }\end{array}$ & $\begin{array}{l}\text { shared rental } \\
\text { flat ( } 2 \text { y) }\end{array}$ & $\begin{array}{l}\text { wife moved to } \\
\text { Finland }\end{array}$ & rental flat (1 y) & $\begin{array}{c}\text { moved closer to } \\
\text { workplace }\end{array}$ & rental flat (1 y) & $\begin{array}{l}\text { tenure } \\
\text { change }\end{array}$ & $\begin{array}{l}\text { owned flat } \\
\text { (2 y) }\end{array}$ \\
\hline G & 2003 & 9 & $\begin{array}{l}\text { temporary rental } \\
\text { flat }(1 \mathrm{~m})\end{array}$ & $\begin{array}{c}\text { moved } \\
\text { closer to } \\
\text { workplace }\end{array}$ & $\begin{array}{l}\text { shared rental flat } \\
(2 \mathrm{y})\end{array}$ & $\begin{array}{l}\text { wife moved } \\
\text { to Finland }\end{array}$ & rental flat ( 3 y) & $\begin{array}{c}\text { moved closer to } \\
\text { workplace }\end{array}$ & rental flat (3 y) & $\begin{array}{l}\text { contract } \\
\text { ended }\end{array}$ & $\begin{array}{l}\text { rental flat } \\
(2 \mathrm{y})\end{array}$ \\
\hline C & 2005 & 7 & $\begin{array}{l}\text { temporary rental } \\
\text { flat }(3 \mathrm{~m})\end{array}$ & contract ended & \multirow{2}{*}{ rental flat (2 y) } & \multirow{2}{*}{ child was born } & \multirow{2}{*}{ rental flat (2 y) } & \multirow{2}{*}{$\begin{array}{l}\text { moved closer to } \\
\text { workplace }\end{array}$} & \multirow{2}{*}{$\begin{array}{l}\text { rental flat } \\
(6 \mathrm{~m})\end{array}$} & \multirow{2}{*}{$\begin{array}{l}\text { tenure } \\
\text { change }\end{array}$} & \multirow{2}{*}{$\begin{array}{c}\text { owned semi- } \\
\text { detached } \\
\text { house }(2 \mathrm{y})\end{array}$} \\
\hline B & 2006 & 6 & & & & & & & & & \\
\hline D & 2007 & 5 & $\begin{array}{l}\text { temporary rental } \\
\text { flat }(4 \mathrm{~m})\end{array}$ & contract ended & rental flat (5 y) & & & & & & \\
\hline $\mathrm{L}$ & 2007 & 5 & $\begin{array}{c}\text { rental flat (relocation services) (2 } \\
\text { y) }\end{array}$ & tenure change & $\begin{array}{c}\text { owned house } \\
(3 \mathrm{y})\end{array}$ & & & & & & \\
\hline 0 & 2007 & 5 & rental flat ( 2 y) & $\begin{array}{l}\text { husband moved } \\
\text { to Finland }\end{array}$ & rental flat ( 3 y) & & & & & & \\
\hline$E$ & 2008 & 4 & $\begin{array}{l}\text { rental flat (relocation } \\
\text { services) }(2 \mathrm{y})\end{array}$ & switched jobs & $\begin{array}{c}\text { rental flat } \\
\text { (relocation } \\
\text { services) (2 y) }\end{array}$ & & & & & & \\
\hline M & 2008 & 4 & $\begin{array}{l}\text { rental flat (relocation services) } \\
\text { (1y) }\end{array}$ & $\begin{array}{c}\text { needed cheaper } \\
\text { flat }\end{array}$ & rental flat ( 2 y) & tenure change & $\begin{array}{c}\text { owned flat } \\
(1 \mathrm{y})\end{array}$ & & & & \\
\hline N & 2008 & 4 & rental flat (1 y) & $\begin{array}{l}\text { wanted a higher } \\
\text { quality dwelling }\end{array}$ & rental flat (1 y) & $\begin{array}{l}\text { moved to India } \\
\text { and then back to } \\
\text { Finland }\end{array}$ & rental flat (1 y) & tenure change & $\begin{array}{l}\text { owned flat } \\
\text { (1 y) }\end{array}$ & & \\
\hline 1 & 2010 & 2 & rental flat (1 y) & $\begin{array}{c}\text { needed cheaper } \\
\text { flat }\end{array}$ & rental flat (1 y) & & & & & & \\
\hline A & 2011 & 0 & rental flat $(7 \mathrm{~m})$ & & & & & & & & \\
\hline $\mathrm{H}$ & 2011 & 1 & $\begin{array}{l}\text { temporary rental } \\
\text { flat }(2 \mathrm{~m})\end{array}$ & $\begin{array}{l}\text { found suitable } \\
\text { house }\end{array}$ & $\begin{array}{l}\text { rental house } \\
\text { (relocation } \\
\text { services) (1 y) }\end{array}$ & & & & & & \\
\hline J & 2011 & 1 & $\begin{array}{c}\text { rental flat (relocation services) (1 } \\
\text { y) }\end{array}$ & & & & & & & & \\
\hline K & 2011 & 1 & $\begin{array}{l}\text { temporary rental } \\
\text { flat }(1 \mathrm{~m})\end{array}$ & $\begin{array}{c}\text { found suitable } \\
\text { house }\end{array}$ & $\begin{array}{l}\text { rental house } \\
\text { (relocation } \\
\text { services) (1 y) }\end{array}$ & & & & & & \\
\hline
\end{tabular}

Table 3. The housing careers of Indian migrants in Helsinki (data collected in 2012) 
The Table 3 illustrates the effects of structural restrictions as well as the interviewees' own actions. Most of the moves were made because temporary rent contracts ended, families grew when spouses moved to Finland or children were born, interviewees wanted to live closer to their workplaces or wanted to become homeowners. Importantly, the interviewees did not mention facing discrimination in the housing market; it seems that in this sense, the societal structures do not constrain the housing choices of this ethnic minority, as discussed by e.g. Aalbers (2002) and Andersson (1998). However, their choices were constrained (Sarre 1986) in some aspects: for example, the housing offered by the employers was available in certain blocks or neighbourhoods, and some of the rental contracts were temporary. On the other hand, the table shows that in many cases the migrants had the possibility of living in a dwelling that was arranged by their employer not only in the beginning of their housing career in Finland, but also later during their stay. It has to be noted that the chart is overly simplified and naturally does not grasp the complex meanings and negotiations that are involved in the dwellings and moving decisions. In many cases, interviewees mentioned many reasons for moving, of which there was usually one main reason (e.g. wife moved to Finland and more space was needed) and supporting reasons (e.g. the current flat was not in a good condition).

The positive aspects of current housing arrangements included a convenient location near services and work, and the availability of public transportation. The analysis shows that the interviewees had moved closer to their workplaces when they had a chance. This finding illustrates how the migrants were active shaping their housing situation to correspond better to their needs, which is an important aspect of a housing pathways approach (Robinson et al. 2007). It also contradicts common notions on the urban preferences of the "creative class" (Florida 2004), since most of the 
workplaces were located outside the city centre. Furthermore, some of them also mentioned the presence of natural elements such as forest, sea and urban green areas as the best features of their current housing. They appreciated the safety in their neighbourhoods and in the city in general. The overall functionality of life in Finland was frequently compared to housing experiences in India, which one of the interviewees summed up as follows:

Safety is a problem, pollution is a problem... mosquitos are a problem. Dust is a problem. Power is a problem. There is a long list of problems. [...] crime is a huge issue $[\ldots]$ (male, 36 , business and administration)

A housing pathways approach highlights the meanings of housing to the residents, as well as their interactions with other people and the societal structures related to housing. Given their Indian background, the interviewees raised some issues that reflect cultural preferences in housing. They said, for example, that they would prefer a dwelling with a separate kitchen and living room so as to keep cooking fumes inside the kitchen, a preference that is also referred to in Agrawal's (2006) study. Flats in Finland tend to have a common kitchen and living area, which the interviewees found impractical. The findings reveal a mismatch between what Morris \& Winter (1975) call the cultural norms and the family norms of housing: immigrants bring their normative orientation with them when migrating, and assess the housing conditions in the host country accordingly.

Another aspect that several of them mentioned was the silence and the desertedness in Finnish neighbourhoods. India is much more heavily populated than Finland, and the migrants missed the crowds and the constant presence of people. 
Skilled migrants' difficulties in establishing a social life in Finland (Merimaa \& Oilinki 2010; Koskela 2014) are therefore also present in the context of the residential area.

[Neighbourhood Y] is a quite good place for me because I came from a country of crowded people... For some Finns [neighbourhood Y] is a little bit crowded (laughs) but for me, I can see people, that's what I like. (male, 35, science)

From the viewpoint of a housing pathways approach, the strong link between social interaction and residential satisfaction is not surprising. For many interviewees, there was a strong social aspect in the meaning of housing in their lives which was built on their previous experiences. The interviewees described that in India, neighbours interact on a daily basis and celebrate public holidays together. In Finland, it is not uncommon that neighbours do not know each other, especially in the urban housing blocks. When facing a different situation in Finland, the interviewees felt that their expectations regarding the social aspect of housing were not met. However, two of the interviewees specifically praised Finnish neighbours for being friendly, but not obtrusive, as they did not miss the close socialising with neighbours in India.

The negative aspects of the housing market in the HMA that were mentioned included the high level of rents and property prices. This is not surprising. There has been a housing shortage for years because the demand is very high. A recent survey of European cities (Quality of life... 2013, 63-64) ranked Helsinki among the top three (with Paris and Amsterdam) with regard to the number of respondents disagreeing with the statement, 'It is easy to find good housing at a reasonable price'. Many interviewees also discussed the size of the dwellings, which they considered too small compared to their previous experiences, and in many cases also too small to accommodate visiting 
family members from India.

[The] first time I came here and I told my father I'm living in 23 square meters, he said come back (male, 33, science)

Some of the migrants also expressed disappointment with the housing quality. Accommodation in Helsinki is expensive, but at the same time it lacks top-end housing choices. As Clapham $(2005,30)$ aptly remarks, 'The meaning attached to a house may be part of a personal identity and lifestyle that includes type of employment, choice of clothing, type of car owned and so on.' Almost all of them had spent their childhood in detached houses, and they were used to having spacious homes. Those in top positions and enjoying high incomes in particular contrasted Finnish housing quality with their previous experiences. They had lived abroad in places such as the US, Malaysia and Dubai, where luxurious housing is available for the elite. The Finnish housing stock is somewhat homogenous, and it is hard to find detached houses for rent, for example, given that most rental accommodation is in blocks of flats. As Table 3 shows, two recently arrived, well-earning migrants rented houses as soon as they found a match to their needs. The alternatives for rental houses were not generally satisfying:

Some of the houses were quite rundown, so old [...] In India we had a house where every room has a bathroom attached to it. So we had a four-bedroom house which every room will have a bathroom. Here a big house will have only one. (male, 37, business and administration)

Interestingly, some of the higher earners among the interviewees brought up the 
lack of affordable domestic and maintenance services as a negative aspect of housing in Finland. These interviewees told that they are not used to doing their own renovations and prefer to employ other people, but they found these services too expensive and saw no point in using them. The fact that the service providers did not necessarily speak English also made it difficult. The egalitarian welfare state does not offer the same services and amenities the elite enjoyed in India, and also in the US, for example.

In India you can afford services, you can afford a maid, you can afford a plumber, carpenter or any service you want. (male, 29, business and administration)

As Clapham (2002, 67-68) has noted, "[h]ousing is increasingly viewed by households as a means to an end - personal fulfilment - rather than as an end in itself". One interviewee aptly summed up the differences between living in a Nordic welfare state and in a country in which income differences are more notable.

[My husband's] first wish is to have a swanky car, his first wish is to have a swanky apartment. [...] And he knows while in Finland it's always going to be comfortable, practical and organised, but not swanky. [...] From my point of view, I like that it's egalitarian [...] You will never have someone who would deliver yoghurt to your apartment unless you are willing to pay 25 euros for that. I don't mind it. (female, 28, business and administration) 


\section{Homeownership and the Myth of Return}

Interviewer:

Well if you would move to a new dwelling here, what would be the ideal option for you? Like a dream house or...?

Female, 33, science: $\quad$ Oh... Dream house I can build only in India.

Homeownership has been considered an expression of commitment to the host country (Murdie and Teixeira 2003). It is suggested in previous studies that the myth of return affects migrants' housing choices and their integration into the host society (Dahya 1974; Anwar 1979). I asked the interviewees about their future plans and whether they would like to return to India at some point in their lives. Four of them expressed an intention to move back to India, another four said they did not wish to move back, and the remaining seven were unsure about where they would like to live in the future. In the following I analyse the relationship between these intentions and homeownership.

As mentioned, four of the interviewees said they intended to return to India. Two of them owned property there, which was a concrete indicator of their intention to return. A female informant working in the field of human resources describes her investment perspective:

Just from a purely investment point of view it makes more sense to invest back home in India, which is what we did [...]things are becoming more and more expensive, so if I don't buy an apartment in India now, ten years later even if my salary is bigger, the market would have expanded so much $[\ldots]$ the other thing is that I do intend to go back home [...]Maybe next year, maybe in ten years but that's the final plan, so I would rather have a place there than here. (female, 29, 
business and administration)

One of the four interviewees who did not want to move back to India was hoping to move back to the US, where he had lived for over ten years. The other three were planning to stay in Finland. One of them had bought a flat, and described the purchase as an economic decision, with no elements of emotion or attachment related to it:

\footnotetext{
We thought we needed to purchase an apartment because we were paying too much rent. So we started looking for an apartment we can afford and we can buy. [...] We decided on [neighbourhood $\mathrm{X}$ ] because there is a metro coming up so we thought we also wanted the resale value so whenever we move out we can either resell it or the other option which we are looking at is rather than reselling if we can rent it out and still pay back our loan. (male, 29, business and administration)
}

Most of the seven interviewees who were not sure about their future plans, and especially those who had temporary working contracts, mentioned career prospects as the major factor in choosing where to live. However, some said that having children might increase the likelihood of their moving back to India where help from the family is available. This demonstrates how the migrants are active in "life planning" (Clapham, 2005: 30). Five of the seven interviewees with no fixed aspirations had purchased property in Finland.

Eventually pretty much everybody was getting married, and everyone started to think of the same thing, does it make sense to pay money for rentals, or then live together in your own place. So two of our friends also live in [neighbourhood X], 
they also started to look similar time as we did. [...] my husband and our friends and everybody, they were discussing and it made sense to buy our place. (female, 28 , business and administration)

Purchasing a dwelling was not a commitment to stay in Finland for these skilled Indian migrants. The purchase was made after careful consideration of the economic facts. The high level of rents in the Helsinki metropolitan area pushed them into homeownership because paying large amounts in rent did not seem rational. The interviews did not highlight homeownership as a means of ensuring security, safety or stability, which are typical connotations especially among lower-income households (Vassenden 2014). The positive experiences of the buying process among friends also encouraged these migrants to take the step to homeownership. They found the buying process smooth, one interviewee describing how everything worked "like a dream", and only one couple felt that they did not receive enough information and help from their estate agent.

Social relations seemed to have quite a strong effect on the buying decisions. All the Indians I interviewed said they were in regular contact with other Indians living in the city region, who in most cases constituted their primary group of friends. As indicated in the previous citation, the buying process is discussed among friends who can offer insights and practical advice on bureaucracy issues, and recommend suitable areas or properties. One interviewee had even ended up as his friend's neighbour:

We and friends of ours searched for apartments together, so both of us now live actually in the next apartments. And then there are at least a couple more who have now moved over after we moved. So now there are in total about four friends, four families living there. (male, 29, business and administration) 
The choice of neighbourhood was based on property prices and expected resale values, the presence of other Indians and what friends recommended as 'good' neighbourhoods (see Meier 2015). According to the interviews, socialisation among Indian friends often takes place at someone's home, and friends' neighbourhoods become familiar during these visits. The importance of co-ethnic friends' recommendations and even physical proximity echoes the findings of Robinson et al. (2007) regarding the housing of Somali and Pakistani immigrants in Sheffield. However, unlike in their study, the proximity to these social resources did not overshadow the Indians' need for a "good" neighbourhood. Another significant factor for the interviewees was proximity to the workplace: many of them worked long hours, and thus wanted a short commute.

Indians are not a homogenous group, being divided by regional and linguistic differences. However, immigration can reinforce national identity and the sense of belonging to an Indian community (Saxenian 2006, 72-73). The Indians I interviewed showed some signs of 'incapsulation' (Anwar 1979): they maintained their Indian culture in celebrating Indian festivals, lived close to their Indian friends and socialised mainly with other Indians. This differs from Harvey’s (2008) description of British and Indian scientists in Boston, who socialised mainly with the host population. It resembles the "co-native bubbles" of French migrants in London, which offer support but also weaken their attachment to the local population (Mulholland \& Ryan 2015).

According to Kim (2014), many skilled migrants working in the US on a temporary contract ultimately decide to settle in the host country because their family enjoys living there and they are used to the American lifestyle. Only three of the 15 Indians I interviewed planned to stay in Finland. One reason for this could be that in 
maintaining close relations with other Indians they remained distant from Finnish culture and found it harder to develop an attachment to the country or the lifestyle. It is also possible that establishing social networks with Finns has been difficult, and other Indians offer an easier group to socialize with.

\section{Conclusions}

As the global competition for talent accelerates, city regions need to assess their competence in terms of hosting and settling skilled migrants. This applies especially to somewhat unusual destinations such as Helsinki, which might lack experience in absorbing diverse people into local communities. It is therefore somewhat surprising that, whereas the housing of ethnic minorities is a well-researched topic, the housing of skilled migrants remains understudied.

This study has served as an exploratory study on how to analyse highly skilled migrants' housing pathways (Clapham 2005), investigating how meaning and experiences of housing are socially constructed in the lives of these migrants. In taking local structures and the agency of the migrants into account I analysed the factors affecting residential satisfaction among skilled migrants, as well as how their intentions to stay or leave were reflected in their housing choices.

In the case of these Indian migrants, the first step on their housing career in Finland was generally a positive experience, every interviewee having received help in finding accommodation when they moved to the country. However, in the longer run they were dissatisfied with the price-quality ratio of housing: prices are high but the quality is not always good enough. Furthermore, those working in top positions with good salaries found the Finnish housing market lacking in top-class alternatives, reflecting their housing experiences. In this particular context, the Helsinki metropolitan area, the housing market and the social environment in the neighbourhoods did not fulfil 
the expectations and needs of the migrants. This finding gives a reason to doubt their staying in the city region, since residential satisfaction has been shown to play an important role in whether people move away from or stay in their current location, and soft factors, such as quality of housing, has been shown to be an important factor in in retaining skilled migrants in a city region.

These Indian migrants mentioned the lack of affordable services as a downside of Finnish housing. Looking at their housing pathways, it was clear that many of them had grown up in an environment in which domestic help was common and available.Besides appreciating the characteristics of Nordic residential areas such as safety, greenness and functionality, the interviewees did not generally highlight the qualities of the welfare state.

Homeownership among Indian interviewees living in Helsinki was clearly related to economic, structural and social factors, and was not a sign of emotional attachment to the host country. This is different than in the case of lower socioeconomic immigrant groups, as suggested in the literature. There is evidence that the myth of return affects the housing choices of these skilled migrants, as previous studies have described, but the socio-economic position changes the situation somewhat. Migrants who know they will return to their home country may think it is not rational to invest money in housing in Finland. On the other hand, this more affluent migrant group has more abundant economic resources than immigrant groups studied thus far, and could temporarily allocate more of them to Finland. This aspect highlights the investment side of buying property and the aim to guarantee added value and saleability.

However, it is worth pointing out that the myth of return is not the only influence on the housing choices of migrants: the surrounding society and the local housing market also affect the decisions. The experiences of the Indian migrants I 
interviewed reveal how their housing situations evolved in interplay between their own choices and local structures. The welfare state creates a particular setting in which homeownership is encouraged, housing costs are high and the associated services are expensive. The Indians who had the necessary economic capital utilized the local structures: they actively discussed tenure and neighbourhood choices with their friends and entered homeownership to save money compared to paying high rents. On the other hand, the limited offer of types of dwellings and household services was something they had to get accustomed to. Discussing their future housing plans, it was clear that their "life planning" involved housing, employment and family pathways which were intertwined and transnational in nature.

A housing pathways approach offers a suitable framework for studying the housing of skilled migrants. The examination of the migrants' housing pathways, their actions and the structures affecting housing as well as social relations and the meanings attached to housing build a deeper and richer picture on their housing decisions and needs than only presenting the static locations of the migrants, as in the majority of earlier literature on skilled migrants' housing. Importantly, the residential satisfaction of skilled migrants cannot be examined without the knowledge on their previous housing experiences and their cultural backgrounds. This paper has showed that local housing might interfere with attempts to retain high skilled, foreign-born workers in a city region. How could housing policy support the settlement of skilled migrants into a city region? First of all, housing policy in congested housing markets such as Helsinki should be integrated into policies related to attracting talent. It should be acknowledged that the inadequate supply of dwellings and the high price level are not only detrimental to the native population, but also negatively affect the settling and rooting of talent in the city region, therefore constraining local economic development. Given that most 
skilled migrants begin their housing pathway in the host country in private rental accommodation, the supply of reasonably priced rental dwellings should be guaranteed. Second, the interviewees also raised the issue of housing quality, referring to versatility in terms of options at the top end of the housing market; such issues are largely avoided in the current Finnish housing policy. The important role of housing in the desired lifestyle was evident in the interviews. Furthermore, skilled Indian migrants are not the only ones who would benefit from a bigger selection of accommodation. Third, as the interviews showed how the migrants missed social interaction with their neighbours, housing policy should aim to find ways to develop and increase neighbourhood based social ties. Interaction with the native population would enhance the residential satisfaction among skilled migrants and help them in developing attachment to the host country. 


\section{References}

Aalbers, M. B. 2002. "The Neglected Evidence of Housing Market Discrimination in the Netherlands.” Radical Statistics 79: 161-169.

Aalbers, M. B. \& R. Deurloo. 2003. "Concentrated and Condemned? Residential Patterns of Immigrants from Industrial and Non-Industrial Countries in Amsterdam." Housing, Theory and Society 20 (4): 197-208.

Agrawal, S. K. 2006. "Housing Adaptations: A Study of Asian Indian Immigrant Homes in Toronto." Canadian Ethnic Studies 38 (1): 117-130.

Agrawal, S. K. \& A. Lovell. 2010. "High-Income Indian Immigrants in Canada." South Asian Diaspora 2 (2): 143-163.

Alba, R. \& J. Logan. 1992. "Assimilation and Stratification in the Homeownership Patterns of Racial and Ethnic Groups.” International Migration Review 26(4): $1314-1341$.

Andersson, R. 1998. "Socio-spatial Dynamics: Ethnic Divisions of Mobility and Housing in Post-Palme Sweden.” Urban studies 35(3): 397-428.

Andersson, E., P. Naumanen, H. Ruonavaara \& B. Turner. 2007. "Housing, Socioeconomic Security and Risks. A Qualitative Comparison of Household Attitudes in Finland and Sweden.” International Journal of Housing Policy 7(2): 151-172.

Anwar, M. 1979. The Myth of Return. Pakistanis in Britain. London: Heinemann.

Bolt, G. \& R. van Kempen. 2002. "Moving Up or Moving Down? Housing Careers of Turks and Moroccans in Utrecht, the Netherlands." Housing Studies 17(3): 401422.

Borén, T. \& C. Young. 2013. “Getting Creative with the 'creative city'? Towards New Perspectives on Creativity in Urban Policy." International Journal of Urban and Regional Research 37(5): 1799-1815.

Brown, L. A. \& M. D. Webb. 2012. "Home Ownership, Minorities, and Urban Areas: the American Dream Writ Local.” The Professional Geographer 64(3): 332-357.

Burgers, J. \& G. Touburg, G. 2013. "International Mobility of Professional Knowledge from the Global South: Indian IT Workers in the Netherlands." Global Networks 13(4): 517-534.

Burgess, E. 1925. "The Growth of the City: an Introduction to a Research Project". In The city reader, edited by LeGates, R. T. \& F. Stout, $2^{\text {nd }}$ edition, 154-161. London: Routledge. 
Castells, M. 2010. The rise of the network society. $2^{\text {nd }}$ edition. Chichester: WileyBlackwell.

Clapham, D. 2002. "Housing Pathways: a Post Modern Analytical Framework." Housing, Theory and Society 19(2): 57-68.

Clapham, D. 2005. The meaning of housing. Bristol: Policy Press.

Clapham, D., P. Mackie, S. Orford, I. Thomas \& K. Buckley. 2014. "The Housing Pathways of Young People in the UK.” Environment and Planning A 46(8): 20162031.

Clark, W. A. V. 2003. Immigrants and the American Dream. New York: Guilford Press.

Clark, W. A. V., M. C. Deurloo \& F. M. Dieleman. 2006. "Residential Mobility and Neighbourhood Outcomes." Housing Studies 21(3): 323-342.

Conradson, D. \& A. Latham. 2005. "Transnational Urbanism: Attending to Everyday Practices and Mobilities.” Journal of Ethnic and Migration Studies 31(2): 227-233.

Cope, M. 2003. "Coding transcripts and diaries." In: Key methods in Geography, edited by Clifford, N. J. \& G. Valentine G, 445-459. London: SAGE.

Coulson, N. E., S.-J. Hwang \& S. Imai. 2003. "The Value of Owner Occupation in Neighborhoods.” Journal of Housing Research 13(2): 153-174.

Dahya, B. 1974. "The Nature of Pakistani Ethnicity in Industrial Cities in Britain.” In Urban ethnicity, edited by A. Cohen, 77-118. London: Tavistock.

Dekker, K., S. de Vos, S. Musterd \& R. van Kempen. 2011. "Residential Satisfaction in Housing Estates in European Cities: a Multi-Level Research Approach.” Housing Studies 26(4), 479-499.

Dhalmann, H. 2013. "Explaining Ethnic Residential Preferences-The Case of Somalis and Russians in The Helsinki Metropolitan Area.” Housing Studies 28(3), 389-408.

Douglass, J., R. Edelstein \& C. Hoareau. 2011. “A Global Talent Magnet.” Research \& Occasional Paper Series CSHE.9.11 Berkeley: Center for Studies in Higher Education, University of California.

Dunn, K. 2010. "Interviewing." In: Qualitative research methods in human geography, edited by I. Hay, 101-138. Oxford: Oxford University Press.

OECD 2014. "Education at a glance." Accessed 16.9.2014. http://dx.doi.org/10.1787/eag-2014-en>

Fitzpatrick, S., G. Bramley \& S. Johnsen, S. 2013. "Pathways into multiple exclusion homelessness in seven UK cities." Urban Studies 50(1), 148-168.

Florida, R. 2004. The rise of the creative class. New York: Basic Books. 
Yle News (2013). "Foreign specialists' foray into Finland." Accessed 24.4.2014. http://yle.fi/uutiset/foreign_specialists_foray_into_finland/6661309.

"Foreigners in Helsinki 2014.” Statistics 2014:37. City of Helsinki Urban Facts.

Glaeser E. L., J. Kolko \& A. Saiz. 2001. “Consumer City.” Journal of Economic Geography 1(1), 27-50.

Goldman, D.P. \& J.P. Smith. 2001. "Methodological Biases in Estimating The Burden of Out-of-Pocket Expenses." Health Services Research 35(6), 1357-1365.

Harrison, M. 2001. Housing, Social Policy and Difference. Bristol: The Policy Press.

Harvey, W. S. 2008. "The Social Networks of British and Indian Expatriate Scientists in Boston." Geoforum 39(5), 1756-1765.

HRS = Helsinki Region Statistics. 2015a. Helsinki Region Dwelling Stock. Statistics Finland. Accessed 16.7.2015. www.aluesarjat.fi.

HRS = Helsinki Region Statistics. 2015b. Helsinki Region Population. Statistics Finland. Accessed 17.7.2015. www.aluesarjat.fi.

Iredale, R. 2001. "The Migration of Professionals: Theories and Typologies." International Migration 39(5), 7-26.

Kauppinen, T. M. 2002. "The Beginning of Immigrant Settlement in the Helsinki Metropolitan Area and the Role of Social Housing." Journal of Housing and the Built Environment 17(2), 173-197.

Kepsu, K., M. Vaattovaara, V. Bernelius, V. \& E. Eskelä. 2009 "Helsinki: An attractive metropolitan region for creative knowledge workers? The view of transnational migrants". ACRE report 7.5. Amsterdam: AMIDSt.Khoo, S.-E., G. Hugo \& P. McDonald. 2008. "Which Skilled Temporary Migrants Become Permanent Residents And Why?” International Migration Review 42(1), 193-226.

Kim, E. 2014. "The Impact of Corporations on the Settlement of Migrant Workers: Koreans in Alabama, USA." Journal of Ethnic and Migration Studies, published online 15.9.2014.

Koskela, K. 2014. "Boundaries of Belonging: Highly Skilled Migrants and the Migrant Hierarchy in Finland." Journal of Finnish Studies 17(1/2), 19-41.

Lawton, P., E. Murphy \& D. Redmond. 2013. "Residential Preferences of the 'Creative Class"?" Cities 31, 47-56.

Lu, M. 1999. "Determinants of Residential Satisfaction: Ordered Logit vs. Regression Models." Growth and Change 30(2), 264-287.

Lujanen, M. \& H.-Å. Palmgren. 2004. "The Housing Market, Housing Production and 
Housing Standard." In Housing and housing policy in the Nordic countries, edited by M. Lujanen, Nord 2004:7, 23-42.

Magnusson, L. \& A. S. Özüekren. 2002. "The Housing Careers of Turkish Households in Middlesized Swedish Municipalities." Housing Studies 17(3), 465-486.

Massey, D. S. \& N.A. Denton. 1993. American Apartheid. Cambridge: Harvard University Press.

McCann, P. \&. Z. J. Acs. 2011. "Globalization: Countries, Cities and Multinationals." Regional Studies 45(1), 17-32.

Meeus, B. \& P. De Decker. 2015. "Staying put! A Housing Pathway Analysis of Residential Stability in Belgium.” Housing Studies 30(7), 1116-1134.

Meier, L. (2015) "Learning the City by Experiences and Images. German Finance Managers' Encounters in London and Singapore." In Migrant Professionals in the City, edited by L. Meier, 59-74. New York: Routledge.

Merimaa, M. \& I. Oilinki. 2010. "Haven Without a Brand - Baltic Sea Region Seen by Asian Students and Professionals." Study reports 2010(8). City of Helsinki Urban Facts.

Moore, J.C., LL. Stinson \& E.J. Welniak. 2000. “Income Measurement Error in Surveys: A Review."Journal of Official Statistics 16(4), 331-361.

Morris, E. W. \& M. Winter. 1975. “A Theory of Family Housing Adjustment.” Journal of Marriage and Family 37(1), 79-88.

Morris, E. W., S. R. Crull \& M. Winter. 1976. "Housing Norms, Housing Satisfaction and the Propensity to Move." Journal of Marriage and Family 38(2), 309-320.

Mulholland, J. \& L. Ryan, L. 2015. “'Londres Accueil': Mediations of Identity and Place among the French Highly Skilled in London.” In Migrant Professionals in the City, edited by L. Meier, 157-174. New York: Routledge.

Murdie, R. A. \& C. Teixeira. 2003. "Towards a Comfortable Neighbourhood and Appropriate Housing: Immigrant Experiences in Toronto." In The World in a City, edited by P. Anisef \& M. Lanphier, 132-191. University of Toronto Press.

Musterd, S. \& Z. Kovács, eds. 2013. Place-making and Policies for Competitive Cities. Hoboken: Wiley \& Blackwell.

Niedomysl, T. \& H. K. Hansen. 2010. "What Matters More for the Decision to Move: Jobs Versus Amenities.” Environment and Planning A 42(7), 1636-1649.

OSF $=$ Official Statistics of Finland. 2013a. Dwellings and housing conditions. Statistics Finland, Helsinki. 
http://www.stat.fi/til/asas/2013/asas_2013_2014-05-21_tie_001_en.html.

OSF = Official Statistics of Finland. 2013b. Population structure. Statistics Finland, Helsinki.

Accessed

28.8.2014.

http://www.stat.fi/til/vaerak/2013/vaerak_2013_2014-03-21_tie_001_en.html.

Owusu, T. Y. 1998. "To Buy or Not to Buy: Determinants of Home Ownership among Ghanaian Immigrants in Toronto.” The Canadian Geographer / Le Géographe canadien 42(1), 40-52.

Park, R.E. 1915. "The City: Suggestions for the Investigation of Human Behavior in the City Environment.” The American Journal of Sociology 20(5), 577-612.

Peach, C. 1998. "South Asian and Caribbean Ethnic Minority Housing Choice in Britain." Urban Studies 35(10), 1657-1680.

Pethe, H., S. Hafner \& P. Lawton. 2010. "Transnational Migrants in The Creative Knowledge Cities: Amsterdam, Barcelona, Dublin and Munich.” In Place-making and policies for competitive cities, edited by S. Musterd \& Z. Kovács, 163-191. Chichester: Wiley-Blackwell.

Phillips, D., B. Athwal, D. Robinson \& M. Harrison 2014. “Towards Intercultural Engagement: Building Shared Visions of Neighbourhood and Community in an Era of New Migration.” Journal of Ethnic and Migration Studies 40(1), 42-59.

"Population with Foreign Background 2013". Statistics Finland. Accessed 17.7.2015. www.stat.fi/.

"Quality of Life in Cities." 2013. European Commission. Accessed July 17, 2015. http://ec.europa.eu/regional_policy/sources/docgener/studies/pdf/urban/survey201 $\underline{3 \text { en.pdf. }}$

Ratcliffe, P. 2002. “Theorising Ethnic and 'Racial' Exclusion in Housing.” In 'Race', housing and social exclusion, edited by P. Somerville \& A. Steele, 22-39. London: Jessica Kingsley Publishers.

Robinson, D. 2010. “The Neighbourhood Effects of New Immigration.” Environment and Planning A 42(10), 2451-2466.

Robinson, D. \& K. Reeve 2006. Neighbourhood Experiences of New Immigration: Reflections from the Evidence Base. York: Joseph Rowntree Foundation.

Robinson, D., K. Reeve \& R. Casey. 2007. The Housing Pathways of New Immigrants. York: Joseph Rowntree Foundation.

Rodríguez-Pose, A. \& T. D. Ketterer. 2012. "Do Local Amenities Affect the Appeal of Regions in Europe for Migrants?” Journal of Regional Science 52(4), 535-561. 
Rossi, P. H. 1955/1980. Why families move. $2^{\text {nd }}$ edition. Beverly Hills: SAGE.

Raunio, M. 2002. "Suomi globaalitalouden osaajien valintojen kentällä." SENTEpublication 15/2002. University of Tampere: Urban and Regional Studies Group.

Ruonavaara, H. 2003. "Finland." In Globalisation and home ownership, J. Doling \& J. Ford, 53-79. Delft: DUP Science.

Ryan, L. \& J. Mulholland. 2013. "French Connections: The Networking Strategies of French Highly Skilled Migrants in London.” Global Networks 14(2), 148-166.

Sánchez-Ayala, L. 2012. "Interviewing Techniques for Migrant Minority Groups.” In Handbook of research methods in migration, edited by C. Vargas-Silva, 117-136. Cheltenham: Edward Elgar Publishing Limited.

Sarre, P. 1986. "Choice and Constraint in Ethnic Minority Housing: a Structurationist View." Housing Studies 1(2), 71-86.

Sarre, P., D. Phillips \& R. Skellington. 1989. Ethnic Minority Housing: Explanations and Policies. Aldershot: Avebury.

Saxenian, A. 2006. The New Argonauts. Cambridge: Harvard University Press.

Silverman, D. 2006. Interpreting Qualitative Data, $3^{\text {rd }}$ edition. London: SAGE.

Sinatti, G. 2011. “"Mobile Transmigrants' or 'Unsettled Returnees'? Myth of Return and Permanent Resettlement Among Senegalese Migrants.” Population, Space and Place 17(2), 153-166.

Skifter Andersen, H., L. Magnusson Turner \& S. Søholt. 2013. “The Special Importance of Housing Policy for Ethnic Minorities: Evidence from a Comparison of Four Nordic Countries." International Journal of Housing Policy 13(1), 20-44.

Skop, E. 2007. "Asian Indians and The Construction of Community and Identity." In Contemporary Ethnic Geographies in America, edited by I. M. Miyares \& C. A. Airries, 271-290. London: Rowman \& Littlefield Publishers.

Speare, A. 1974. "Residential Satisfaction as an Intervening Variable in Residential Mobility." Demography 11(2), 173-188.

Storper, M. \& M. Manville. 2006. "Behaviour, Preferences and Cities: Urban Theory and Urban Resurgence.” Urban Studies 43(8), 1247-1274.

Vaattovaara, M., K. Vilkama, S. Yousfi, H. Dhalmann \& T. M. Kauppinen. 2010. "Contextualising Ethnic Residential Segregation in Finland: Migration Flows, Policies and Settlement Patterns." In Immigration, Housing And Segregation in the Nordic Welfare States, by R. Andersson, H. Dhalmann, E. Holmqvist, T. M. Kauppinen, L. Magnusson Turner, H. Skifter Andersen, S. Søholt, M. Vaattovaara, 
K. Vilkama, T. Wessel \& S. Yousfi. 2010, 195-262. Department of Geosciences and Geography C2. University of Helsinki.

Valentine, G. 2005. “Tell Me About...: Using Interviews as a Research Methodology." In Methods In Human Geography, edited by R. Flowerdew \& D. Martin, 110-127. $2^{\text {nd }}$ edition. Essex, Pearson.

Van Oort, F., A. Weterings \& H. Verlinde. 2003. "Residential Amenities of Knowledge Workers and the Location of ICT-Firms in the Netherlands." Tijdschrift voor economische en sociale geografie 94(4), 516-523.

Vassenden, A. 2014. "Homeownership and Symbolic Boundaries: Exclusion of Disadvantaged Non-Homeowners in the Homeowner Nation of Norway." Housing Studies 29(6), 760-780.

Wadhwa, V., A. Saxenian, B. Rissing \& G. Gereffi. 2008. "Skilled Immigration and Economic Growth.” Applied Research in Economic Development 5(1), 6-14.

Walsh, K. 2014. "Placing Transnational Migrants through Comparative Research: British Migrant Belonging in Five GCC Cities." Population, Space and Place 20(1), 1-17. White, P. 1998. "The Settlement Patterns of Developed World Migrants in London." Urban Studies 35(10), 1725-1744.

White, P. \& Hurdley, L. 2003. International Migration and the Housing Market: Japanese Corporate Movers in London. Urban Studies 40(4), 687-706.

Wiesel, I. 2014. "Mobilities of Disadvantage: the Housing Pathways of Low-Income Australians." Urban Studies 51(2), 319-334.

Wyly, E. K., D. G. Martin, P. Mendez \& S. R. Holloway. 2010. "Transnational Tense: Immigration and Inequality in American Housing Markets." Journal of Ethnic and Migration Studies 36(2), 187-208.

Yanasmayan, Z. 2015. "Further Stay or Return? Insights from the Highly Educated Turkish Migrants in Amsterdam Barcelona and London.” In Migrant professionals in the City, edited by L. Meier, 21-39. New York, Routledge.

Yigitcanlar T., S. Baum \& S. Horton. 2007. “Attracting and Retaining Knowledge Workers in Knowledge Cities.” Journal of Knowledge Management 11(5), 6 - 17.

Zetter, R. 1999. "Reconceptualizing the Myth of Return: Continuity and Transition amongst the Greek-Cypriot Refugees of 1974." Journal of Refugee Studies 12(1), $1-22$.

Özüekren, S. \& R. van Kempen 2003. "Dynamics and Diversity: Housing Careers and Segregation of Minority Ethnic Groups.” Housing, Theory and Society 20(4), 162- 
171. 